\title{
Engaging ESP Students with Brain-Based Learning for Improved Listening Skills, Vocabulary Retention and Motivation
}

\author{
Ashraf Atta Mohamed Safein Salem ${ }^{1}$ \\ ${ }^{1}$ Department of Languages \& Linguistics, College of Business Administration, Sadat Academy for Management \\ Sciences, Egypt \\ Corresponding: Ashraf Atta Mohamed Safein Salem, Department of Languages \& Linguistics, College of \\ Business Administration, Sadat Academy for Management Sciences, Egypt. E-mail: sirashrafams@hotmail.com
}

Received: October 5, 2017 Accepted: November 7, $2017 \quad$ Online Published: November 10, 2017

doi: 10.5539/elt.v10n12p182 URL: http://doi.org/10.5539/elt.v10n12p182

\begin{abstract}
The concept of teaching and learning has changed drastically over the past few years by the virtue of both research results carried out in the fields of second/Foreign language learning and acquisition. Of all these researches, findings related to the brain structure and functions in cooperation with cognitive aspects of the education process, including the study of learning styles and intelligence have struck the language learning domain. A due understanding of learners' learning styles, emotional preferences as well as their memory functions help teachers to build their teaching practices to optimize students' learning. Brain Based Learning Approach (BBLA) is a natural, motivating, and a positive way that supports and maximizes learning and teaching. The current study implements Brain Based Learning Approach to improve listening skills of Business students, vocabulary retention and establish positive attitudes with regards to their brain dominance and learning styles. To achieve these aims, listening skills test, vocabulary retention test, adapted form of Robert Gardner Motivation Scale, were developed and used. The sample of the study consists of thirty six Business majors. Findings show that Brain Based Learning is an effective approach for developing listening skills, consolidate vocabulary recalling and retention. It also helps maximize motivation towards learning language skills.
\end{abstract}

Keywords: Brain- based Learning, listening skills, vocabulary retention, motivation

\section{Introduction}

Learning is a complex process, despite the advent of several teaching and learning theories, approaches and strategies. The ultimate goal teachers aspire to achieve is to get their students involved and hopefully engaged in the lesson through carefully selected teaching practices. Teachers' success to use effective instructional practices is a guarantee to maximize students' learning and optimize their motivation, involvement and engagement. Spada and Lightbown (1999) argue that learners have clear preferences for their learning, if teachers take into account learners' individual characteristics and preferences, they can create better learning conditions that triggers meaningful learning. Therefore, paying a due attention to the learners' personal characteristics, learning styles, and traits exaggerate the possibility of leaning meaningfully.

Teaching practices that cope with the way learners think and feel are the most effective ones to "enhance learners' motivation, thereby increasing their academic achievement" (Kok, 2010). Among effective teaching approaches is the Brain Based Learning Approach (BBLA), it refers to a learning method which concerns the characteristics the brain is naturally designed to learn (Jensen, 2000). It is a teacher facilitated approach that utilizes learner's cognitive endowments as it is based on brain-based learning principles (Thomas \& Swamy, 2014).

Traditionally, teaching strategies focused mainly on what teachers do or able to do at classroom with no attention to the learners' characteristics. On the contrary, Learner-centered approach to teaching and learning pay a due attention to what learners can do to maximize their learning rather their teachers. Respress and Lutfi (2006) view that traditional teaching approaches, students rush to learn through a basic curriculum designed with homogenous learning styles with no consideration of students' learning styles and preferences. This leads to lack of enjoyment, boredom, and underachievement.

Unlike traditional approaches to teaching and learning that inhibit learning through ignoring brain's natural 
learning processes, learner-centered approaches such as BBLA, maximizes learning as it addresses learners' whole personal traits, it is a holistic approach towards learning. Jensen (1996) states that Brain Based Learning favors the brain's natural operational principles so as to attain maximum attention, understanding, meaning and memory.

\subsection{Relevant Literature}

\subsubsection{Brain Based Learning Strategies}

Brain-based Learning Approach (BBLA) depends mainly on twelve main brain compatible learning and teaching principles: the brain is a parallel processor, learning engages the entire physiology, the search for meaning is innate, the search for meaning occurs through patterning, emotions are critical to patterning, the brain processes parts and wholes simultaneously, learning involves both focused attention and peripheral perception, learning always involves conscious and unconscious processes, learning depends on both spatial memory system and a set of systems, understanding and remembering best achieved once facts and skills are embedded in natural and spatial memory, learning is enhanced by challenge and inhibited by threat, and also each brain is unique (Moghaddam \& Araghi, 2103).

Brain based learning is a strategy that deployed teaching practices via three instructional techniques; relaxed alertness, orchestrated immersion, and active processing (Caine \& Caine, 1991).

a. Relaxed Alterness: Providing relaxing teaching/learning environment creates optimal emotional and social climate for learning. Relaxed though challenging teaching environment with minimal threats provides effective learning practices (Gulpinar, 2005). Learners' interest in the material taught optimizes their learning, and relaxed brain triggers learn. Therefore, teachers should do their best to eliminate fear in learning environment (Caine, Caine, \& Crowel, 1999; Gozuysil \& Dikicl, 2014; Thomas \& Swamy, 2014).

b. Orchestrated Immersion: Effective teaching practices involve student's concentration on the contents they learn. Learners also have to use memory to explore the content that is characterized with holistic and correlative nature (Caine \& Caine, 2002).

c. Active Processing: Learners with active brains achieve meaningful learning through memory work that relate new objects to the ones already exists in the cognitive structure (Duman, 2007). Thus, teachers should allow learners to consolidate and internalize information through active processing (Caine \& Caine, 1991).

Brain Based Learning need to be understoond to be effectively used in the classroom. It may used through certain principles Caine and Caine (1991) stated:

1) The brain is parallel processor.

2) Lerning engages the entire physiology.

3) The search for meaning is innate.

4) The search for meaning occurs through "patterning".

5) Emotions are critical to patterning.

6) The brain process parts and wholes simultaneously.

7) Learning involves both focused attention and peripheral perception.

8) Learning always involves conscious and unconscious processes.

9) We have at least different types of memory: a spatial memory system and a set of systems for rote learning.

10) We understand and remember best when facts and skills are embedded in natural, spatial memory.

11) Learning is enhanced by challenge and inherited by threat.

12) Each brain is unique.

Brain hemispherity controls learning process, limiting students' experience to more left hemisphere activities, such as repeated instruction geared to facts and details, sequential ordering, lecture/ discussions, drill and practice and textbook readings, results in an inconsistent learning environment (Darcy Jack, 2010). Therefore, learner-centered teaching environments represent an endeavor to assist learners to make connections between their previous knowledge and their current academic tasks (Bransford, Brown, \& Cocking, 2000). Focusing on the brain functions, thus, help paying attention to sensory perception, attention, memory and how emotions affected learning (Yandow, 2007).

Left, middle and right brain dominants need certain teaching practices; left-brain dominants teachers prefer to 
teach using structured lectures, and prefer giving assignements and activities such as research papers, debates, and book reports that are written as opposed to presented or drawn. On the other hand, right-brain dominants are intuitive and emotional, they specialize in processing a lot of information simultaneously through seeing the whole picture, thus, teachers tend to lecture less, instead involving them in projects. Middle-brain dominants are more balanced than either left or right- brain people. (Connell, 2005)

\subsubsection{Advantages of Brain Bsed Lerning in Educational Settings}

\subsubsection{BBLA Provides Meaningful Lerning}

Learners' involvement and engagement in materials taught is a direct result of meaningful lerning techniqes teachers adopts. Thoms and Swamy (2014) state that meaningful learning occurs when faculty transmit from teacher-centered educational settings to one is learner-centered environment. Learners' roles in learner-centered approach are maximized through the minimization of teachers' dominance. In learner-centered approach, teachers must develop learners' understanding of course content through classroom environment enrichment, this type of environments include physical, emotional, and social aspects that invert the classroom environment from teaching setting to learning arena (Kaufman et al., 2008).

Developing meaningful learning experiences can be achieved through integrating the engagement of emotions, enriched environments, music, movement. Meaning making and the absence of threats maximizes learners' participation, involvement and engagement that leads to better undestnding and academic achievement (Sousa, 2004, Luna, 2004).

Brain Based Learning Approach helps facilitating meaningful language learning through the natural way brain work to help learners to use languge in a meaningful context. Using such a brain compatible approach undoubtedly follows the spontaneous techniques learners use their brains. Spontaneous learning experiences maximize the learning opportunities and make learning last longer. According to Wolfe (2001), Brain based learning is relevant and meaningful to previous mental, emotional, and physical experiences strengthen memory. Caine and Caine (2006) view that each brain system within the whole brain seems to work collaboratively to provide meaningful learning. It admits the brains' roles in meaningful learning and adapting teaching with the brains' roles. Springer (2010) states that students find new information presented more meaningful if it relates to personal life. Therefore, the materials used should inseparable from the daily life to be meaningful. Real life experiences and events "are etched in our minds with no difficulty, the brain searches to make sense of experiences." (Van Roekel, 2002)

\subsubsection{BBLA Helps Vocabulary Retention}

Memory is not a unitary concept and the different areas of the brain join in the encoding and retrieving tasks (Moghadam \& Araghi, 2013). The essence of teaching using BBLA is that it implies understanding how the brain works best to increase learning to the highest degree (Pool, 1997). Therefore, teaching English language through BBLA does not focus on enhancing academic achievement for short time, but it enhances the possibilities of keeping information and knowledge learned for a long time.

It is a way to improve learning and teaching capacity and outcomes, it includes understanding how the brain learns effectively, and how to optimize brain state and functioning to best support learning and teaching. Mindfulness improves attention, emotion and self-control, it also helps knowledge, character and wisdom-based education(Tang, 2017). It is worth noting that learning becomes stronger and information retrieval becomes easier if sesnse are involved, also, experiences linked to emotions are easier to remember. Brain based instructional strategies help students to practice that make information permanent. Moreover, it employs stories in teaching that engages many area in the brain, subsequently, it engages many different emotional triggers that are helpful in retrieving information (Sprenger, 2010).

Brain-based learning is a framework which takes account of how the brain processes and interprets information, also makes connections, stores and retrieve those messages (Greenleaf, 2003). It offers language learners a brain-friendly way to teach (Sun, 2012). Therefore, it fosters retrieving information through the use of grphic organizers due to the premise that brains seek patterns. According to Willis (2006), patterns are passageways for memories to follow, the best way to set up the passageways is to use graphic organizers and chuncking information.

\subsubsection{BBLA Exaggerates Learning Motivation}

Learning through Brain-based learning is a natural, motivating, and positive way to maximize learning as it follows the ways our brains work (Jensen, 2005, Caine, 2006). Changing teaching and learning environment from teacher-centered approach to learner-centered learning environments secure, safe and non-threatening 
learning experiences that maximize learners' enthusiasm and motivation to learn (Moghadam \& Araghi, 2013).

Brain-based learning enhances students' learning through challenge and inherited by threats, it provides challenging, but not impossible tasks to encourage them to strive (Krashen, 1988, Haghighi, 2013). Non-threatening learning environment stimulates learning experiences depending on working in pairs or groups, reflecting on ideas, thinking creatively through using a variety of resources. Stress inhibits learning, teachers who provide a relaxing environment are, the more successful among others. Lowering stress requires finding a comfort level in the environment and with people in that environment (Sprenger, 2010).

According to Smilkstein (2003), when students are given the opportunity to experience activities and teaching environments that are compatible with the brains' natural learning systems to be critical and creative thinkers, students then learn successfully, naturally and with motivation. On the contrary, when imposing an unnatural teaching environments where information is filtered through an objective lens, learning becomes something static, limited and permanent, rather than open-minded, evolving and dynamic (Darcy Jacj, 2010).

\subsection{Listening Skills}

Listening skills are essential for communication with others to serve social purposes, good listeners accumulate information and knowledge of the surrounding environment. Therefore, rich surrounding environments provides learners with vivid stimuli that help them to acquire listening skills, practice is also a crucial element in the acquisition process, listening skills should be continually practiced otherwise it gradually diminishes. Language learning depends mainly on listening, students' learning will decrease without the proper level of listening.

Despite its importance, listening is probably the most neglected skill or rather the least explicit of the four skills of English language (Vandergrift, 2004). Therefore, it is the most difficult skill to learn. According to Nunan (1997), listening is a Cinderella skill as it is the most ignored skill among the four language skills. Listening skill is usually neglected and "overlooked by its "elder sister- speaking" (Rashtchi, Khiabani, \& Rooumiani, 2012), it is used to be a frowned upon part of any instructional language program (Shesgelani, Sadeghoghli, \& Aidinlou, 2013).

Goh (2008) states that listening skills have received no due attention since the 1960s as it was heavily influenced by reading and writing pedagogy. Listening skills - according to Goh and Taib (2006) - are a stressful task, especially for beginning and intermediate learners. This may be due to different factors, including cognition and affect. Therefore, teachers are advised to encourage learners to take their responsibility towards their own listening development.

Listening is a complex, active process and a problem-solving skill, listeners must undertake certain processes such as discriminating between sounds, understanding vocabulary and grammatical structures, interpreting stress and intonation, retaining what was gathered in all of the previous skills, and interpreting it within the immediate as well as larger socio-cultural context of the utterance (Vandergrift, 1999; Armstrong \& Rentz, 2002; Brown, 2006; EI-Basel, 2008; Wang, 2011).

The lack of these skills makes listeners unable to interpret the messages they received from the speakers. Adrian (1993, as cited in Armstrong \& Rentz, 2002) views that most people only hear about 50\% of the messages they receive and often misinterpret what they do hear. Therefore, the difficulty of listening lies in the inability to interpret the messages that they listen to hand by hand with their inability to distinguish linguistic as well as paralinguistic features of the spoken discourse.

Listening comprehension, as a receptive skill, depends on students' ability to decode the speaker's message and on the intelligibility of the speaker. Listeners may ask for repetition or rephrasing. In this sense, listening is an active reception of a message (EI-Basel, 2008). Therefore, listening comprehension involves the listener's ability to understand the speaker's pronunciation, grammar, vocabulary he/she uses at the same time in order to figure out the message delivered by the speaker.

Listening takes place to achieve certain goals, whether academic or non-academic; getting the main ideas, listening for details, and listening for making inferences (Brown, 2006,). In addition, listening can serve achieving academic purposes, it is essential for students to achieve academic success in the classroom, thus, attaining higher levels of thinking, educators need to emphasize better listening skills. Listening is a skill that can be learned and improved upon no matter one's age, gender, education, or previous skill level, like other skill, if it is allowed to go unused, it will atrophy (Armstrong \& Rentz, 2002). 


\subsection{Relevant Past Research}

One line of research investigating engaging non-native students in classroom activities to develop English language proficiency hand in hand with certain language skills that encourage and motivate students to learn English in a non-native environment has recommended focusing on the role of brain in language learning (Yagcioglu, 2014; Gozuyesil \& Dikici, 2014; Kapadia, 2014; Thomas \& Swamy, 2014). In recent years, lots of new approaches have been used in ELT classes to help students learn, or hopefully to involve and engaged in the language learning process (Yagcioglu, 2014).

Brain-based learning supports learning experiences through the discovering plethora of strategies to maximize learning (Carolyn, 1997), it associates learning with the brain and the way it works, the positive effects of the brain features to develop the brain and enhance learning (Gozuyesil \& Dikici, 2014). It also helps engaging students in language learning (Jensen, 2000, 2005). Vocabulary retention is previlaged through the use of Brain based learning approach (Haghighi, 2013; Tüfekçi \& Demirel, 2009).

Listening skills, whether cognitive or metacognitive skills, can be duly improved through the use of Brain based learning, it was also revealed that listening comprehension can be enhanced (Kok, 2014). Contrary to the commonly held belief, listening is anything but a passive activity, rather, it is an active process of discriminating sounds, understanding vocabulary and grammatical structures, interpret stress and intonation, retain what was gathered in all of the above and interpreting it through a larger sociocultural context of the utterance (Vandergrift, 1999). It includes making meaning from the oral input based upon the background "schemata" (Byrnes, 1984, Young, 1997), listeners use a plethora of mental processes to give meaning to information they listen to (Coskun, 2010), it therefore represents a meaningful learning experience. Also, it includes producing information in the long term memory to help listeners to make their own interpresentations of the spoken language (Bidabdi, 2011).

In their endeavors to acquire the basic components of the language, learners adopt different learning styles and preferences such as field dependance/ independance, hemispheric dominance, representational systems and learning strategies that facilitate learning processes (Kok, 2010). Teachers should pay a due attention to students' learning styles and preferences to better design their teaching and instructional practices to optimize the students' learning experiences inside and outside the classroom (Saleh, 1997). Brain based instructional teaching methods actively deploy these principles, actively responds to students' learning styles and preferences, and enhance students' opportunities to get interested, involved and engaged in the learning process, learning becomes an interesting experience for non-native diversified proficiency level students.

\subsection{Need for the Study}

Arab educational systems produce deaf and mute English language learners, this is due to ignoring teaching listening and speaking skills. Language learning practices focus mainly on teaching and practicing reading and writing skills, whereas the two other skills have been ignored for a long time due to certain assumptions; the complexity of these skills, anxiety related with these skills, the lack of native-speaking environments and the lack of effective testing and evaluation techniques.

EFL learners rarely have an adequate chance to listen to the target language, they also lack the environment in which they can practice English inside or outside classrooms, they find no opportunities to speak or listen at schools and homes as they speak using their mother tongue not the target language. Good listeners may fail to be competent not because of the difficulty in listening, rather because there are certain situational factors that may influence the listener and affect their ability to listen effectively.

Language learning has changed over the past few years of total teachers' dominance in the classroom to learner-centered approach that maximized the learners' roles. Teaching English as a foreign language is a part of the educational process which was affected fundamentally by the scientific, technological and the cultural advancements reflected in every field of our daily life. Students have varied abilities, expectations, motivation level, knowledge and different learning styles. The change from teacher-centered to student-centered approach to learning means changing the teacher's role from being a lecturer or director to be just a facilitator leaving a scope for students to be initiative (Goodnough, 2001; Kallenback \& Viens, 2002; Haley, 2004; Scapens, 2007).

According to Redical; Tomaszewski and Weaver (2003), teachers should find the right strategies to fit the diverse learning styles of each individual within the classroom setting. Student metacognition, thinking about one's own thinking, and motivation to read, the eight multiple intelligences need to be incorporated into everyday classroom learning.

The learner - centered approach helps greatly to develop teaching practices in the ESL / EFL classroom. It is based on "andragogy" rather than "pedagogy" which make the learner the cornerstone in the educational process. 
According to the learner-centered approach "the teacher's role is a facilitator, with the student acting as a reflective partner" (Haley, 2004). It is a holistic approach to learning with a developmental and socio-cultural perspective based on the structure and the functions of the human brain (Caine \& Caine, 1995). Brain-based approach to learning and teaching is based "on the ways our brain learns best" (Jensen, 2005). It includes admitting the brain's rules for meaningful learning and adapting teaching with those rules in the brain (Caine and Caine, 2006).

Brain-based learning focuses on the way the brain works, multiple intelligences, learning styles, is a vivid example of learner-centered approaches to learning and teaching. The teacher is a guide and facilitator or even a "reflective practitioner" whereas students took responsibility of their learning; they are a reflective partner in their learning. In addition, these theories believe that learning is a whole person process (Haley, 2004).

McCombs, (2002), Cluck and Hess (2003) suggested that there are various ways to motivate children, depending on how they learn. Students' natural curiosity about the surrounding world can be sparked through more meaningful materials, among these is the Brain- based learning.

\subsection{Research Questions}

In light of gaps in repeated research, three questions were explored:

* Do the Brain-based learning strategies used in this study promote the listening skills of ESP students?

* Do the Brain-based learning strategies used in this study promote the vocabulary retention of ESP students?

* Do the Brain-based learning strategies used in this study create positive motivation towards learning English for ESP students?

\section{Method}

\subsection{Participants}

Thirty six (19 males and 17 females) second year Egyptiam business majors in the college of Business Administration, Sadat Academy for Management Sciences, with a mean age of 19.6 years. All were Egyptian Business majors and had received their Business English language education in a university setting for an average one year. The participants exhibited similar (intermediate) listening skills in English, (poor) vocabulary retention and negative motivational levels towards learning English. A Multiple choice pre-post listening and vocabulary retention test based on Intelligent Businesss coursebook (Tony \& Graham, 2005) was used to assess the basic level of students' listening skills side by side with the vocabulary retention.

\subsection{Materials}

\subsubsection{Listening Skills Pre-Posttest}

The listening pre-posttest was used to assess listening skills of business students, these skills are: listening for the general ideas (orientation listening), listening for details, listen to take notes, listen to recognize new vocabulary, summarizing and recounting. It consists of six sectionsthat represented the core of the teaching course of the study. Designing the test was based on reviewing pertinent viewpoints of EFL specialists and reviewing related literature. The total score of the test was 50 multiple-choice items.

Validity of the listening pre-posttest was assured through submitting the test to a panel of jury members to decide on its suitability and appropriacy in addition to the statistical processes. Reliability of the listening skills Pre-posttest was calculated through the inter-rater reliability procedures; two raters participated in scoring the listening skills test, each rater was given a separate copy of the test papers to score by himself, scores given by the two raters were correlated using Pearson Formula, the correlation coefficient between the first and second rater is (0.943) at significance level (0.01).

\subsubsection{Vocabulary Retention Test}

During the study, the participants' vocabulary was tested twice: once before the experiment (vocabulary pretest) and postetested after the treatment using Breain based instructional strategies. Vocabulary retention pre-posttest consists of (50) items including three main test types; multiple-choice, complete and Matching questions. In the pre-post vocabulary retention test, the participants were told to answer each item only if and when they could recognize the word that they thought constituted the best choice, the good completing match, or the best match for the definition provided. This was to ensure that the participants would choose words they knew rather than opt for the unknown target word through random guessing. 


\subsubsection{Motivation Scale}

The short form of Robert Gardner (1985) Attitude/Motivation Test Battery (AMTB) was used. It is a 7-point scale, ranging from 'extremely low' to 'extremely high'. The AMTB short form is reported to have good reliability and validity (Gardner, 1985; 1980; Gardner \& Smythe, 1981) and the internal consistency estimate of reliability for the modified questionnaire was calculated, and Cronbach's Alpha was 0.93. Since the students came from different academic and socio-economic backgrounds with different levels of proficiency in English, the questionnaire was administered in the mother tongue. However, the major focus in this study was on different types of motivational orientations (instrumental and integrative) and the attitudes of the students regarding the language (positive and negative). Integrative Orientation scale includes four items to find out how much the learners learn English with a genuine interest to assimilate with the target language, culture ,community, their way of life, literature etc.; this would show their integrativeness towards the target language. On Instrumental Orientation scale, there are four items and the respondents are asked to measure their utilitarian reason for learning English. The short form AMTB scale has twelve items to investigate the student's attitude toward learning English as a second language.

\subsubsection{The Listening Course}

The listening course was mainly based on Intelligent Business (Trappe \& Tullis, 2005), it is combined BBLA to Listening skills instruction, where the learners were taught a number of the listening skills though three main BBLA strategies; Relaxed Alterness (Caine, Caine, \& Crowel, 1999; Gulpinar, 2005; Gozuysil \& Dikicl, 2014; Thomas \& Swamy, 2014), Orchestrated Immersion (Caine \& Caine, 2002) and Active Processing (Caine \& Caine, 1991; Duman, 2007).

The listening course aims to develop the listening skills of second year business students. Based on this general aim of the program, the general objectives related to the units in the program were determined. These objectives were as follows:
a. Top-down strategies
1. Predict/ anticipate text content and vocabulary
2. Guess meaning of unknown content and vocabulary
3. Infer unstated aspects of text; use context to facilitate comprehension
4. Use discourse markers to guess, anticipate
b. Bottom-up strategies
1. Use stressed word
2. Use discourse mrkers
3. Identify stresses content words

These objectives were scaled down into behavioral objectives for each session.

\subsection{Design and procedures}

One group pre-posttest test experimental design in which only one group was used in the implementation process. The quasi-experimental design was adopted. This group was exposed to a listening pre-posttest and a training program based on Brain-bsed learning approach to develop the students' listening skills, vocabulary retention and create motivation of ESP students.

The study was comprised of the following stages: (1) recruitment of participants; (2) Hemispheric dominance Scale (Eric Jorgenson, 2015): (3) Short form AMTB pre testing; (4) Listening Skills Pre-test; (5) Vocabulary retention Pre-test; (6) Business English Listening course implementation; (7) Short form AMTB post-testing; (8) Listening Skills Post-testing; (9) Vocabulary retention Post-testing.

\subsection{Data Collection Methods}

Quantitative instruments were used to collect the data through the formal data collection timeline. Qualitative instruments were also used such as the researcher observation of the learners and of their work, and informal interviews with them sometimes conducted after class. The instruments were piloted and refined prior to the main study with other groups of learners of similar proficiency level as the participants.

\section{Results}

With regard to the research question, the following information can be provided: 
Table 1. Differences in listening skills with regard to brain dominance

\begin{tabular}{llllllll}
\hline Brain Dominance & N. & Group & Mean & SD & t value & $\mathrm{p}$ value & Significance Level \\
\hline Right & 17 & Pretesting & 24.53 & 4.32 & 11.5 & .06 & $\mathrm{p} \geq 0.05$ \\
& & posttesting & 36.11 & 3.35 & & & \\
Middle & 9 & Pretesting & 25.77 & 4.92 & 9.52 & .05 & $\mathrm{p} \geq 0.05$ \\
& & posttesting & 35.00 & 5.19 & & & \\
Left & 10 & Pretesting & 24.40 & 4.81 & 9.49 & .02 & $\mathrm{p} \geq 0.05$ \\
& & posttesting & 36.40 & 5.35 & & & \\
\hline
\end{tabular}

It is clear that there are significant statistical differneces between the mean scores of the experiemental group in the pretesting and posttesting of the listening skills of ESP university students with regards to their brain dominance for both middle and left brain oriented. Improvement in listening skills of ESP university students tends to be larger in students using their right and left hemispheres compared with those who are neutral in their thinking styles brain dominance.

Table 2. Differences in vocabulary retention with regard to brain dominance

\begin{tabular}{|c|c|c|c|c|c|c|c|}
\hline Brain Dominance & $\mathrm{N}$. & Group & Mean & SD & $\mathrm{t}$ value & $p$ value & Significance Level \\
\hline \multirow[t]{2}{*}{ Right } & \multirow[t]{2}{*}{17} & Pretesting & 26.12 & 5.22 & \multirow[t]{2}{*}{11.60} & \multirow[t]{2}{*}{.06} & \multirow[t]{2}{*}{$\mathrm{p} \geq 0.05$} \\
\hline & & posttesting & 38.70 & 5.31 & & & \\
\hline \multirow[t]{2}{*}{ Middle } & \multirow[t]{2}{*}{9} & Pretesting & 28.22 & 5.26 & \multirow[t]{2}{*}{3.31} & \multirow[t]{2}{*}{.7} & \multirow[t]{2}{*}{$\mathrm{p} \geq 0.05$} \\
\hline & & posttesting & 36.77 & 6.45 & & & \\
\hline \multirow[t]{2}{*}{ Left } & \multirow[t]{2}{*}{10} & Pretesting & 27.90 & 4.01 & \multirow[t]{2}{*}{4.57} & \multirow[t]{2}{*}{.2} & \multirow[t]{2}{*}{$\mathrm{p} \geq 0.05$} \\
\hline & & posttesting & 38.30 & 7.70 & & & \\
\hline
\end{tabular}

Table 2 shows that the memory practices have been positively affected due to the use Brain-based strategies, engaging ESP students in activities hand in hand with interesting authentic listening material help vocabulary retention. Right brain dominants are the above average achievers in vocabulary retention tasks. It is shown that brain hemispherity affects memory and recalling activities and tasks.

Table 3. Differences in motivation with regard to brain dominance

\begin{tabular}{llllllll}
\hline Brain Dominance & N. & Group & Mean & SD & t value & $\mathrm{p}$ value & Significance Level \\
\hline Right & 17 & Pretesting & 37.00 & 5.50 & 36.71 & .00 & $\mathrm{p} \geq 0.05$ \\
& & posttesting & 66.94 & 6.25 & & & \\
Middle & 9 & Pretesting & 34.11 & 6.56 & 11.61 & .06 & $\mathrm{p} \geq 0.05$ \\
& & posttesting & 63.55 & 8.00 & & & \\
Left & 10 & Pretesting & 43.55 & 7.35 & 11.45 & .11 & $\mathrm{p} \geq 0.05$ \\
& & posttesting & 69.11 & 6.91 & & & \\
\hline
\end{tabular}

Again, left brain dominant experimental group students are the privileged in terms of motivation. It seems that middle and right brain dominants have been less motivated in the Brain-based instruction with its interesting and challenging activities and tasks. Therefore, the three groups; right, middle and left brain dominants are motivated in language teaching activities based on the brain but with different degrees according to their brain dominance. 
Table 4. Differences in listening skills with regard to learning styles

\begin{tabular}{|c|c|c|c|c|c|c|c|}
\hline Brain Dominance & $\mathrm{N}$. & Group & Mean & SD & t value & $\mathrm{p}$ value & Significance Level \\
\hline \multirow[t]{2}{*}{ Kinesetic } & \multirow[t]{2}{*}{10} & Pretesting & 27.50 & 3.59 & \multirow[t]{2}{*}{10.85} & \multirow[t]{2}{*}{.03} & \multirow[t]{2}{*}{$\mathrm{p} \geq 0.05$} \\
\hline & & posttesting & 37.40 & 3.56 & & & \\
\hline \multirow[t]{2}{*}{ Audio } & \multirow[t]{2}{*}{9} & Pretesting & 22.66 & 3.96 & \multirow[t]{2}{*}{8.81} & \multirow[t]{2}{*}{.19} & \multirow[t]{2}{*}{$\mathrm{p} \geq 0.05$} \\
\hline & & posttesting & 35.22 & 4.35 & & & \\
\hline \multirow[t]{2}{*}{ Write/Read } & \multirow[t]{2}{*}{12} & Pretesting & 23.58 & 4.85 & \multirow[t]{2}{*}{8.50} & \multirow[t]{2}{*}{.13} & \multirow[t]{2}{*}{$\mathrm{p} \geq 0.05$} \\
\hline & & posttesting & 35.16 & 4.15 & & & \\
\hline \multirow[t]{2}{*}{ Visual } & \multirow[t]{2}{*}{5} & Pretesting & 24.50 & 4.37 & \multirow[t]{2}{*}{12.83} & \multirow[t]{2}{*}{.09} & \multirow[t]{2}{*}{$\mathrm{p} \geq 0.05$} \\
\hline & & posttesting & 34.66 & 4.93 & & & \\
\hline
\end{tabular}

Concerning Business students' listening skills with regards to their preferred learning styles, it is clear that students that best learn through movement and action have been privileged in this experiement. Students with kinesetic learning style achieved better than those who prefer using auditory, written, or visual materials on the contrary to the premise that listening skills are closely related to the auditory materials that better help them to develop listening skills.Students who do the task and using their senses achieve better than their mates in the listening tasks.

Table 5. Differences in vocabulary retention with regard to learning styles

\begin{tabular}{|c|c|c|c|c|c|c|c|}
\hline Brain Dominance & $\mathrm{N}$. & Group & Mean & SD & t value & $\mathrm{p}$ value & Significance Level \\
\hline \multirow[t]{2}{*}{ Kinesetic } & \multirow[t]{2}{*}{10} & Pretesting & 28.70 & 5.01 & \multirow[t]{2}{*}{5.45} & \multirow[t]{2}{*}{.4} & \multirow[t]{2}{*}{$\mathrm{p} \geq 0.05$} \\
\hline & & posttesting & 39.70 & 5.59 & & & \\
\hline \multirow[t]{2}{*}{ Audio } & \multirow[t]{2}{*}{9} & Pretesting & 26.22 & 5.47 & \multirow[t]{2}{*}{4.109} & \multirow[t]{2}{*}{.6} & \multirow[t]{2}{*}{$\mathrm{p} \geq 0.05$} \\
\hline & & posttesting & 37.22 & 6.86 & & & \\
\hline \multirow[t]{2}{*}{ Write/Read } & \multirow[t]{2}{*}{12} & Pretesting & 27.16 & 4.76 & \multirow[t]{2}{*}{5.42} & \multirow[t]{2}{*}{.19} & \multirow[t]{2}{*}{$\mathrm{p} \geq 0.05$} \\
\hline & & posttesting & 37.66 & 6.99 & & & \\
\hline \multirow[t]{2}{*}{ Visual } & \multirow[t]{2}{*}{5} & Pretesting & 23.66 & 4.88 & \multirow[t]{2}{*}{6.91} & \multirow[t]{2}{*}{.01} & \multirow[t]{2}{*}{$\mathrm{p} \geq 0.05$} \\
\hline & & posttesting & 36.00 & 6.06 & & & \\
\hline
\end{tabular}

On the other hand, students with visual learning style preference are better achievers in vocabulary retention tasks of business nature. It is clear that differences between the pretesting and postetesting scores of business students in vocabulary retention tasks are statistically significant for students who prefer learning through visual materials. Such findings seem to be logical as relevant previous literature shows that using visual materials, tasks and activities help recalling process. The use of organizers whether graphic or advanced graphic organizers has been proved to be fruitful for memory tasks and recalling activities.

Table 6. Differences in motivation with regard to learning Styles

\begin{tabular}{|c|c|c|c|c|c|c|c|}
\hline Brain Dominance & N. & Group & Mean & SD & $\mathrm{t}$ value & $\mathrm{p}$ value & Significance Level \\
\hline \multirow[t]{2}{*}{ Kinesetic } & \multirow[t]{2}{*}{10} & Pretesting & 34.50 & 5.50 & \multirow[t]{2}{*}{24.24} & \multirow[t]{2}{*}{.07} & \multirow[t]{2}{*}{$\mathrm{p} \geq 0.05$} \\
\hline & & posttesting & 65.00 & 6.43 & & & \\
\hline \multirow[t]{2}{*}{ Audio } & \multirow[t]{2}{*}{9} & Pretesting & 29.44 & 6.24 & \multirow[t]{2}{*}{17.93} & \multirow[t]{2}{*}{.01} & \multirow[t]{2}{*}{$\mathrm{p} \geq 0.05$} \\
\hline & & posttesting & 55.00 & 9.04 & & & \\
\hline \multirow[t]{2}{*}{ Write/Read } & \multirow[t]{2}{*}{12} & Pretesting & 33.00 & 7.63 & \multirow[t]{2}{*}{14.04} & \multirow[t]{2}{*}{.01} & \multirow[t]{2}{*}{$\mathrm{p} \geq 0.05$} \\
\hline & & posttesting & 65.25 & 13.31 & & & \\
\hline \multirow[t]{2}{*}{ Visual } & \multirow[t]{2}{*}{5} & Pretesting & 37.83 & 9.15 & \multirow[t]{2}{*}{8.17} & \multirow[t]{2}{*}{.01} & \multirow[t]{2}{*}{$\mathrm{p} \geq 0.05$} \\
\hline & & posttesting & 65.16 & 15.17 & & & \\
\hline
\end{tabular}


It is clear from Table 4 that the Brain based learning activities employed in the current study have been effective in stimulating business majors to improve both their listening skills hand in hand with vocabulary enrichment as a step forward to get high scores in international testing services such as TOEFL and TOEIC as it is one of the main requirements for graduation. Business majors with auditory, written and visual learing styles preferences have been motivated higher than their mates who prefer learing through doing and acting. It seems that students with kinesthetic learning style preference are naturally motivated in terms of experimenting materials to learn, therefore, it can be argued that those students need no extrinsic motivation as they have a great deal of intrinsic motivation to learn.

\section{Discussion and Conclusions}

\subsection{Discussion}

The study addressed the effect of implementing Brain based instruction into language teaching to Business majors in terms of their brain dominance and learning styles. Findings showed a large gains in the listening skills, vocbulry retention as well as postitve attitude towards language learning stemed from intrinsic and extrinsic motivation triggered through interesting activities used. The brain dominance is one of the two main controlling variables in the current study; people differ in the way they think as they use only one the brain hemispheres; right, left or even the middle.

Concerning the listening skills, it seems that the middle left brain dominants achieved better than their right and middle brain dominants putting in mind the small number of them compared with the right brain dominants.

This finding may be logical due to the nature of left brain dominants as they are characterized by their tendancy towards verbal language and system analysis, also, they are eager to use order in thinking and to think in a rational way. These features may help them to develop listening skills. Results of this type coincide with those obtained in the study of Kok (2014) showing the left brain dominants to achieve better than other brain domains in language learning.

Another finding that seems to be interesting is that right brain dominants have achieved larger gains in vocabulary retention test compared with their middle and left brain dominant mates. Right brain dominants are characterized by being dreamy, they are imaginative and creative in general as well as when they learn a language. Therefore, those students are privileged with their brain dominance hand in hand with the interesting material through Brain based strategies. Again, such findings coincide with the study conducted by Oflaz (2011) indicating that right brain dominants are privileged in vocabulary retention and writing skills.

In addition, statistical differences between the pretestting and posttesting of the Short form of Gardner AMTB show big gains in favor of right brain dominants compared with the scores of middle and left brain dominance although the latter gains well in the term of motivation. Right brain dominants'main characteristics are being free in their thinking, they are rich in emotions and imaginations. Those students are self motivated to learn the language in addition to the interesting and motivation activities teachers adopting Brain based instruction use. Therefore, those students already got intrinsic motivation stemmed from their personal characteristic hand in hand with extrinsic motivation enriched through the use of Brain based strategies.

Results focusing on the positive impact of using Brain-based approach on motivational aspects of language learning have been twinned with those results obtained from Yagcioglu (2014) indicating the effectiveness of using Brain-based instruction in ELT classes.

The second main issue of the current study focuses on the impact of implementing Brain based learning on improving listening skills, vocabulary retention and motivation with regards to their learning styles. Students with kinetic learning style achieved better than other learning style preferences (Auditory, written/ Read, and Visual), yet all of them achieved well in the listening pre-post test. Students with such preference are eager to learn through doing and action, they listen to authentic business audio materials through doing and performing what they listen to, it makes information embedded in the listening material easy to be understood, thus, it helps language learners to improve their listening skills.

Another point relates to Business majors achievement in vocabulary retention test, it is clear that viusaul language learners achieves better than other learning styles prefereants. It is logical for students with visual learning styles are apt to learn, sustain and recall business vocabulary due to their ability to visualize business vocabulary students taught, seeing words or images of these words help students greatly to remember these words especially they were taught in functional contexts.

Concerning the motivational aspect of Business major learning English through implementing Brain-based instruction, three learning styles preferants are highly motivted to learn language skills specially those under 
discussion; listening skills and business English vocabulary, these three learning styles are auditory, written/ read, and visual language learners. It seems that motivation relates with a due care to use audio, written and visual materials, whether listening comprehension or vocabulary items, therefore, motivation levels of those learners are comparatively higher than students with kinestic learning style preference.

\subsection{Limitations and Directions for Future Research}

Despite the positive results of this study, several limitations should be noted. First, the study is mainly based on the results of ESP contexts. Consequently, it remains unclear whether such techniques promote other aspects of vocabulary knowledge. Also, the listening material used is closely related to authentic materials Business major are subject to in their academic study and later on at work environments. Therefore, it is not for sure similar results can be obtained in other general or academic contexts.

The third limitation concerns the lack of a control group. Although the participants exhibited improved listening skills, significant vocabulary retention, and high level of intrinsic and extrinsic motivation, doubt is covering the assumption that similar results can be obtained if a control group were included. Thus, alternative assessment methods are probably necessary to gauge the effectiveness of Brain-based learning approach on developing the dependent variables.

Direction of the future research may revolve around the e-brain based language learning due to the technological advancements happened these days. Education policymakers in the Arab region should employ such improvements inside schools and university for better language teaching and learning environments.

\section{Conclusions and Pedagogical Implications}

A great deal of the study findings seems to be natural and logical in terms of relevant previous literature results and the actual teaching and learning practices. Based on three main teaching strategies; relaxed alterness, orchestrated immersion, and active processing (Caine \& Caine, 1991, 2003), Brain based instruction is an effective teaching approach. Language learning can be an interesting and motivating experience proved that students work in a relaxed environment. This brain motivating teaching experience triggers the innate desire for meaning stimulation.

Implementation of Brain based instruction helps learners with active brains to achieve meaningful learning through memory work that relate new objects to the ones already exists in the cognitive structure (Duman, 2007). Other teachers should take advantage of such findings to allow learners consolidate and internalize information through active processing (Caine \& Caine, 1991).

Brain based teaching techniques used in the experiment help learner to activate brain functions that cope with their learning styles. Language learning in a non threatening environment ensures positive emotions leading to positive attitudes towards the learning process and the learned materials. Language learning becomes a challenging experience in favor of using activities and tasks that depend on brain structure and functions. Learners' interest in the material taught optimizes their learning, and relaxed brain triggers learn. Therefore, teachers should do their best to eliminate fear in learning environment.

In addition to providing a relaxing, non-threatening environment that helps students to stimulate meaningful learning and emotional support that motivate students to learn, the holistic nature of Brain based learning helps memory to work better in exploring and understanding the content provided instead of mere memorizing mere words segregated from its context.

It is taken for granted that neuroscience coupled with education in the current study to help language learners not to develop academic achievement or language proficiency, rather it focuses on developing skills and motivational aspects. Learners are responsible for their own learning, teaching and learning activities are based mainly on what learners can do and what they can learn. The learner - centered approach helps maximize the students' authority through the minimization of teachers' dominance. As a learner-centered approach, teachers in the Brain-based instruction should do their best to develop learners' understanding of course content through classroom environment enrichment. The healthy teaching environment should provide physical, emotional, and social aspects that enunciate interesting and motivating learning experience.

\section{Declaration of Conflicting Interests}

The author declares that there is no conflict of interest.

\section{Funding}

This research received no specific grant from any funding agency in the public, commercial, or not-for-profit sectors. 


\section{References}

Armstrong, S., \& Rentz, T. (2002). Improving Listening Skills and Motivation. Master of Arts Research Project, Saint Xavier University and Skylight Professional Development Field-Based Master's Program. http://www.ericedu.org.eg.doi.468085 CS511269.

Bidabadi, F. S. (2011). The Relationship between listening strategies used by Iranian EFL freshman university students and their listening proficiency levels. English Language Teaching, 4(1), 26-32. https://doi.org/10.5539/elt.v4n1p26

Bransford, J. D., Brown, A. L., \& Cocking, R. (2000). How people lern: Brain, mind, experience, and school. Washington DC: National Academy Press.

Brecher, D., Gray, M., Price, S., \& Sayles, K. (1998). Improving the spelling of high frequency words in daily writing across the curriculum through the use of multiple intelligences.

Brown S., (2006). Teaching Listening. Cambridge: Cambridge University Press.

Byrnes, H. (1984). The role of listening comprehension: A theoretical base. Foreign Language Annals, 17, 317-29. https://doi.org/10.1111/j.1944-9720.1984.tb03235.x

Caine, R., \& Caine, G. (1991). Understanding a brain-based approach to learning and teaching. Education Leadership, 48(2), 66-70.

Caine, R., \& Caine, G. (2003). Taking connection: Teaching and the human Brain. Association for Supervision and Curriculum Development.

Caine, R. N., \& Caine, G. (1995). Understanding a Brain Based Approach to learning and teaching. Educational Leadership, 48(2), 66-70.

Caine, R. N., \& Caine, G. (2006). Meaningful learning and the executive functions of the brain. The Neuroscience of Adult Learning, 5(3).

Carolyn, R. P. (1997). Brain-based learning and students. The Education Digest Ann Arbor, 63(3), 10-15.

Cluck, M. and Hess, D. (2003). Improving Student Motivation through the Use of the Multiple Intelligences. Master of Arts Action Research Project, Saint Xavier University and Skylight Professional Development Field-Based Master's Program.

Connell, J. D. (2005). Brain-Based strategies to reach every learner: Surveys, questionnaire, and checklists that help you identify student's strengths- plus Brain-based lessons and activities for engaging every learner. NY: Scholastic Inc.

Coşkun, A. (2010). The effect of metacognitive strategy training on the listening performance of beginner students. Novitas-ROYAL (Research on Youth and language), 4(1), 35-50.

Darcy Jack, C. (2010). Exploring Brain-based instructional practices in secondary education classes. Doctor of Education, Boise State University.

Duman, B. (2007). Neden Beyin Temelli Ö̈renme? Ankara: PegemA Yayınları.

El-Basel, R. M. (2008). The Effectiveness of Multimedia Program Using Animation to Develop the Speaking Skill in English for the Pupils of the Primary Stage. MA Thesis, Cairo University, Institute of Educational Studies.

Geimer, M., Jennifer, P., \& Terry, P. K. (2000). Improving Student Achievement in Language Arts through Implementation of Multiple Intelligences strategies. Master of Arts Action Research Project, Saint Xavier University and Skylight Professional Development.

Goh, C. (2008). Metacognitive instruction for second language listening development: Theory, practice and research implications. RELC journal, 39(2), 188-213. https://doi.org/10.1177/0033688208092184

Goh, C., \& Taib, Y. (2006). Metacognitive instruction in listening for young learners. ELT Journal, 60(3), 222-232. https://doi.org/10.1093/elt/ccl002

Goodnough, K. (2001). Multiple intelligences theory: A Framework for personalizing science curricula. Journal of school science and Mathematics, 101(4), 180-193.

Gozuyesil, E., \& Dikici, A. (2014). The effect of Brain Based Learning on academic achievement: A Meta-analytical study. Educational Sciences: Theory \& Practices, 14(2), 642-648.

Greenleaf, R. K. (2003). Motion and Emotions. Principle Leadership. May 2003, 14. 
Gulpinar, M. A. (2005). The principles of brain-based learning and constructivist models in education. Educational Sciences: Theory \& Practice, 5(2), 299-306.

Haghighi, M. (2013). The Effect of Brain- Based Learning on Iranian EFL Learners' Achievement and Retention. Procedia - Social and Behavioral Sciences, 70, 508-516. https://doi.org/10.1016/j.sbspro.2013.01.088

Haley, H. M. (2004). Learner-Centered Instruction and the Theory of Multiple Intelligences with Second Language Learners. Teachers College Record, 106(1), 163-180. https://doi.org/10.1111/j.1467-9620.2004.00326.x

Jensen, E. (1996). Brain-based learning. DelMar, California, USA: Turning Point Publishing.

Jensen, E. (2000). Brain-Based Learning: A reality check. Educational Leadership/April, 76-80.

Jensen, E. (2005). Teaching with the brain in mind (2nd ed.). Alexandria, VA: ASCD.

Kallenbach, S., \& Viens, J. (2002). Open to Interpretation: Multiple Intelligences Theory in Adult Literacy Education. Teachers College Record, 106(1), 58-66. https://doi.org/10.1111/j.1467-9620.2004.00318.x

Kapadia, R. H. (2014). Level of awareness about knowledge, belief and practice of brain based learning of school teachers in Greater Mumbai region. Procedia - Social and Behavioral Sciences, 123, 97-105 $1877-0428$.

Kok, I. (2010). The relationship between students' reading comprehension achievement and their attitudes towards learning English and their abilities to use reading strategies with regard to hemispheric dominance. Procedia Social Behavioral Sciences, 3, 144-151. https://doi.org/10.1016/j.sbspro.2010.07.026

Kök, İ. (2014). Listening Comprehension Achievement and Brain Dominance. Procedia - Social and Behavioral Sciences, 122, 329-334. https://doi.org/10.1016/j.sbspro.2014.01.1348

Kornhaber, M. L. (2004). Multiple intelligences: From the ivory tower to the dusty classroom-but why? Teachers College Record, 106, 67-76. https://doi.org/10.1111/j.1467-9620.2004.00319.x

Luna, B., Garver, K. E., Urban, T. A., \& Lazar, N. A. (2004). Sweeney JA. Maturation of cognitive processes from late childhood to adulthood. Child Dev, 75(5), 1357-1372. https://doi.org/10.1111/j.1467-8624.2004.00745.x

McCombs, B. L. (2002). Understanding the Keys to Motivation to Learn. http://www.ncrel.org/products/votewarthy/barbaram.asp.

Missoum, M. (2008). An Investigation of The Lecture Comprehension \& Note Taking Strategies of Second Year Students of English At The University of Blida. MA of Linguistics \& Didactics. Faculty of Arts and Languages. University of Algiers at Bouzareah.

Moghaddam, A. N., \& Araghi, S. M. (2013). Brain-Based aspects of cognitive learning approach in second language learning. English Language Teaching, 6(5), 55-61.

Nunan, D. (1997). Listening in Language Learning. The Language Teacher. The Japan Association of Language Learning, 21(9), 47-51.

Pool, C. R. (1997). Maximizing learning: A conversation with Renate Nummela Caine. Educational Leadership, 54(6), 11-15.

Rashtchi, M., Khiabani, M. N., \& Roumiani, N. (2012). The effect of listening to self audio-taped journals on Iranian EFL learners' grammar knowledge. Advances in Asian Social Sciences, 4(1), 764-768.

Redical, J., Tomaszewski, T., \& Weaver, D. (2003). Improving student Academic Reading Achievement through the use of multiple intelligence teaching strategies. Master's Action Research Project, Chicago, IL: Saint Xavier University.

Repress, T., \& Lutfi, C. (2006). Whole brain learning: The fine arts with students at risk. Reclaiming Children and Youth, 15(1), 24-31.

Saleh, A. (1997). The nexus of brain hemispherity, personality types,temperments, learning styles, learning strategies, gender, majors and cultures. Unpublished Doctorate Dissertation, University of Alabama.

Scapens, M. (2007). Implementing the theory of multiple intelligences in the junior secondary school. Master of Education. The University of Waikato.

Shesgelani, A. P., Sadeghoghli, H., \& Aidinlou, N. A. (2013). The effect of explicit listening comprehension strategy use of Iranian EFL learners. International Journal of social sciences and Education, 3(4), 
1113-1121.

Smilkstein, R. (2003). We are born to learn: Using the brain's natural learning process to create today's curriculum. Thousands Oaks, CA: Crown Press, Inc.

Sousa, D.A. (2004). The ramifications of brain research. School Administrator Web Edition.

Spada, N., \& Lightbown, P. M. (1999). How language are learned. UK: Oxford Handbooks for Language Learners.

Sprenger, M. (2010). Brain based teaching in digital age. Alexandria, VA: ASCD.

Sun, M. (2012). Hard science linguistics and brain-based teaching: the implications for second language teaching. Theses nd Dissertations, 441.http://utdr.utoledo.edu/theses-dissertations/441

Tang, Y. (2017). Brain-based learning and education: Principles and practice. UK: Academic Press, Elsevier.

Thomas, B. M., \& Swamy, S. S. (2014). Brain-Based Teaching Approach- A new paradigm of teaching. International Journal of Education and Psychological Research, 3(2), 62-65.

Trappe, A., \& Tullis, G. (2005). Intelligent Business: coursebook. UK: Pearson Longman Publishing.

Tüfekçi, S., \& Demirel, M. (2009). The effect of brain based learning on achievement, retention, attitude and learning process. Procedia Social and Behavioral Sciences, 1, 1782-1791. https://doi.org/10.1016/j.sbspro.2009.01.316

Van Roekel, B. (2002). Brain-based learning: Implications for the elementary classroom. Master of Education Program Theses, Paper 72.

Vandergrift, L. (1999). Facilitating second language listening comprehension: Acquiring successful strategies. ELT Journal, 53(3), 168-176. https://doi.org/10.1093/elt/53.3.168

Vandergrift, L. (2004). Listening to Learn or learning to listen? Annual Review of Applied linguistics, 24, 3-25. https://doi.org/10.1017/S0267190504000017

Wang, H. (2011). Conversational Implicature in English Listening Comprehension. Journal of Language Teaching and Research, 2(5), 1162-1167. https://doi.org/10.4304/j1tr.2.5.1162-1167

Willis, J. (2006). Research-based strategies to ignite student learning: Insights from a neurologist and classroom teacher. Alexndria, VA: ASCD.

Wolfe, P. (2001). Brain Matters: Translating Research into Classroom Practice, Alexandria, VA: ASCD.

Yagcioglu, O. (2014). The advantages of brain based learning in ELT classes. Procedia - Social and Behavioral Sciences, 152, 258-262. https://doi.org/10.1016/j.sbspro.2014.09.190

Yandow, R. (2007). Improving pedagogy through Brain-based learning. Mathematical and Computing Sciences Masters, Paper 56.

Young, M. Y. C. (1997). A serial ordering of listening comprehension strategies used by advanced ESL learners in Hong Kong. Asian Journal ofEnglish language Teaching, 7, 35-53.

\section{Copyrights}

Copyright for this article is retained by the author(s), with first publication rights granted to the journal.

This is an open-access article distributed under the terms and conditions of the Creative Commons Attribution license (http://creativecommons.org/licenses/by/4.0/). 